\title{
An Observational Study to Assess the Knowledge Regarding Physical Examination among III Year GNM students at Narayana Medical College Hospital, Nellore, Andhra Pradesh
}

\author{
Latha. $\mathrm{A}^{1}$, Latha. $\mathrm{P}^{2}$, Dr. Indira Arumugam ${ }^{3}$ \\ ${ }^{1}$ Professor, Department of MSN, Narayana College of Nursing, Nellore, Andhra Pradesh, India \\ 2 Professor, Department of OBG, Narayana College of Nursing, Nellore, Andhra Pradesh, India \\ ${ }^{3}$ Professor \& Principal, Department of MSN, Narayana college of Nursing. Nellore, Andhra Pradesh, India
}

\begin{abstract}
Background: Physical examination is an integral part of nursing care. It is the basic nursing care. A good physical examination leads to identification of the client - status, strengths and concern for nursing diagnosis. This provides discretion for nursing implementation and alleviation of client concern. Assessing a client health status is a major component of nursing care. A complete health assessment may be conducted starting at the head and proceeding in systematic manner downward (head-to-foot) assessment. Aim: The aim of the study was to assess the level of knowledge physical examination. Objectives: 1 . To determine the level of knowledge regarding physical examination among IIIrd year GNM students. 2. To associate the level of knowledge with selected demographic variables. Methodology: 30 III yr GNM students posted at Narayana Medical College Hospital were selected by using simple random sampling method. Results: Regarding the level of knowledge among GNM III yr students, 6, (20\%) had adequate knowledge, 22(73.3\%) had moderate knowledge and 2(6.6\%) had inadequate knowledge regarding physical examination.
\end{abstract}

Keywords : Knowledge, Physical Examination, GNM Students.

\section{INTRODUCTION}

"Declare the past, Diagnose the present, foretell the Future:" - Hippocrates

Assessing a client health status is a major component of nursing care. A complete health assessment may be conducted starting at the head and proceeding in systematic manner downward (head-to-foot) assessment. Most people need an explanation of the physical examination. The nurse should explain when and where it will take place, why it is important and what will happen during examination. ${ }^{1}$
Physical examination refers to process by which a professional investigate the body of a patient for signs of disease. It generally follows taking medical history an account of the symptoms are experienced by the patient. Together with the Medical history, physical examination aid in determining the correct diagnosis and devising the treatment plan. This data become part of the Medical history. The main purposes of physical examination is to help the doctor determine the general status of the health. It is also help to talk to patient about ongoing pain or symptoms that are experiencing. ${ }^{2}$

Equipment's required for health examination should be clear, in good working order and readily 
accessible. The equipment includes flash light to view pharynx, Cervix and reactions of pupils, Nasal speculum to permit visualization of the lower and middle turbinate's, ophthalmoscope to visualize the inferior eye, tuning fork to test hearing capacity and vibratory sense. Gloves to protect the nurse and Lubricants to ease insertion of instruments. ${ }^{3}$

Preparation of the client include explanation of the physical examination. The nurse should explain when and where it will take place. Health examination are usually painless. However, it is important to determine in advance any position that are contraindicated for a particular client. The sequence of examination differs with children and adult. It is very important to prepare the environment before starting the assessment. The time for the physical examination should be convenient to both the client and the nurse. ${ }^{4}$

The physical examination done in a sequential head to toe fashion to ensure thorough assessment of each system. The method not only prevents the nurse from forgetting to an area it also decreases the number of client have to change position. The nurse performs the physical or the head to toe assessment by using special assessment techniques. These techniques include inspection, palpation, percussion and auscultation. The nurse should position the client to ensure accessibility to body part being assessed. ${ }^{5}$

Normal results of a physical examination correspond to the healthy appearance and normal functioning of the body and normal functioning of the body. Abnormal results of physical examination include any findings that indicated the presence of a disorder, disease or underlying condition. Nursing staff and students should have good skills in performing physical examination to identify the abnormalities which further helps to determine the diagnosis and to plan for quality of patient care. ${ }^{6}$

\section{NEED FOR THE STUDY}

Physical examination is an integral part of nursing care. It is the basic nursing care. A good physical examination leads to identification of the client status, strengths and concern for nursing diagnosis. This provides discretion for nursing implementation and alleviation of client concern. ${ }^{7}$

According to OMICS group (2013) report, 1603 journals, 83 conferences and several workshops are presently dedicated exclusively to physical examination. In terms of research annual, USA, India, Japan, Brazil and, Canada are some of the leading countries where studied related to physical exam native are being carried out. ${ }^{8}$

Acc. to British Journal of Nursing (2013) report, The role of a nurse continues to change with the point where nursing stops and medicine begins become increasingly blurred. Arguably, the main driver for this change could be the recent reduction in junior doctor's working hours. However, modern nursing therapy for innovation and nurses are taking on more and more task and skills that were traditionally part of doctors remit. One example is physical assessment, which has very little evidence to support its use in any setting. ${ }^{9}$

Globally $70-80 \%$ of patients underwent physical examination, about $45-79 \%$ of patients in adult critical care units had physical examination, $38 \%$ in surgical wards and in 3\% rehabilitation units. ${ }^{10}$

Alireza Fazel (2011): conducted a cross- sectional study on 200 nurses working in Isafan Hospital. The data was collected by a researcher made 
questionnaire including two parts: The first part was included demographic data and the second part was included 18 skills in cardiovascular physical examination in two different columns. In the first column, the frequency of using skills and in the second column, the proficiency was self-assessed by nurses. The study concluded that most of nurses used skills to assess the patient with system wise analysis. And fewer nurses' skill was lower than desirable. ${ }^{11}$

\section{PROBLEM STATEMENT:}

An observational study to assess the knowledge regarding physical examination among IIIrd year GNM students at Narayana Medical College and General Hospital, Nellore.

\section{OBJECTIVES}

- To determine the level of knowledge regarding physical examination among IIIrd year GNM students.

- To associate the level of knowledge with selected demographic variables.

\section{DELIMITATIONS:}

The study is limited to;

- The IIIrd year GNM students posted at Narayana Medical College General Hospital.

- The sample size is 30 only.

to keep the city clean by informing about the garbage levels of the bins by providing graphical image of the bins via IOT Php web development platform.

\section{METHODS AND MATERIAL}

\section{Research Approach:}

A quantitative approach was adopted to determine the research study.

\section{Research Design:}

The present study was conducted by using descriptive research design.

\section{Setting:}

Setting of the study was conducted at Narayana Medical College Hospital, Nellore.

\section{Population:}

Target population: All III yr GNM students.

\section{Accessible population:}

III yr GNM students posted at Narayana Medical College Hospital.

Nellore.

\section{Sample:}

III yr GNM students posted at $\mathrm{NMCH}$, Nellore and who fulfilled the inclusion criteria.

\section{Sampling Technique}

Probability-simple random sampling technique was adopted to the selected samples.

\section{Sample Size:}

The sample size selected for the present study includes 30 III yr GNM students.

\section{Criteria for Sample Collection:}

\section{Inclusion Criteria}

- Students of III yr GNM.

- Students posted in NMCH, Nellore.

\section{Exclusion Criteria}

- Those who are not present during the time of data collection.

- Those who are not willing to participate in the study.

Variables of the study:

Independent variable: GNM III yr students.

Dependent variable: Level of knowledge.

Description of the tool: 
Part-A: Demographic variables data include the age, educational qualification, religion, working hours.
Part-B: Self structured questionnaire to assess the knowledge regarding the physical examination among III rd GNM students. It consist of 40 questions.

\section{DATA ANALYSIS AND DISCUSSION}

Table 1: Frequency and percentage distribution of level of knowledge among GNM III yr students $(\mathrm{N}=30)$

\begin{tabular}{|l|l|l|}
\hline Level of Knowledge & Frequency (F) & Percentage (\%) \\
\hline Adequate knowledge & 6 & 20 \\
\hline Moderate knowledge & 24 & 80 \\
\hline Inadequate knowledge & - & - \\
\hline
\end{tabular}

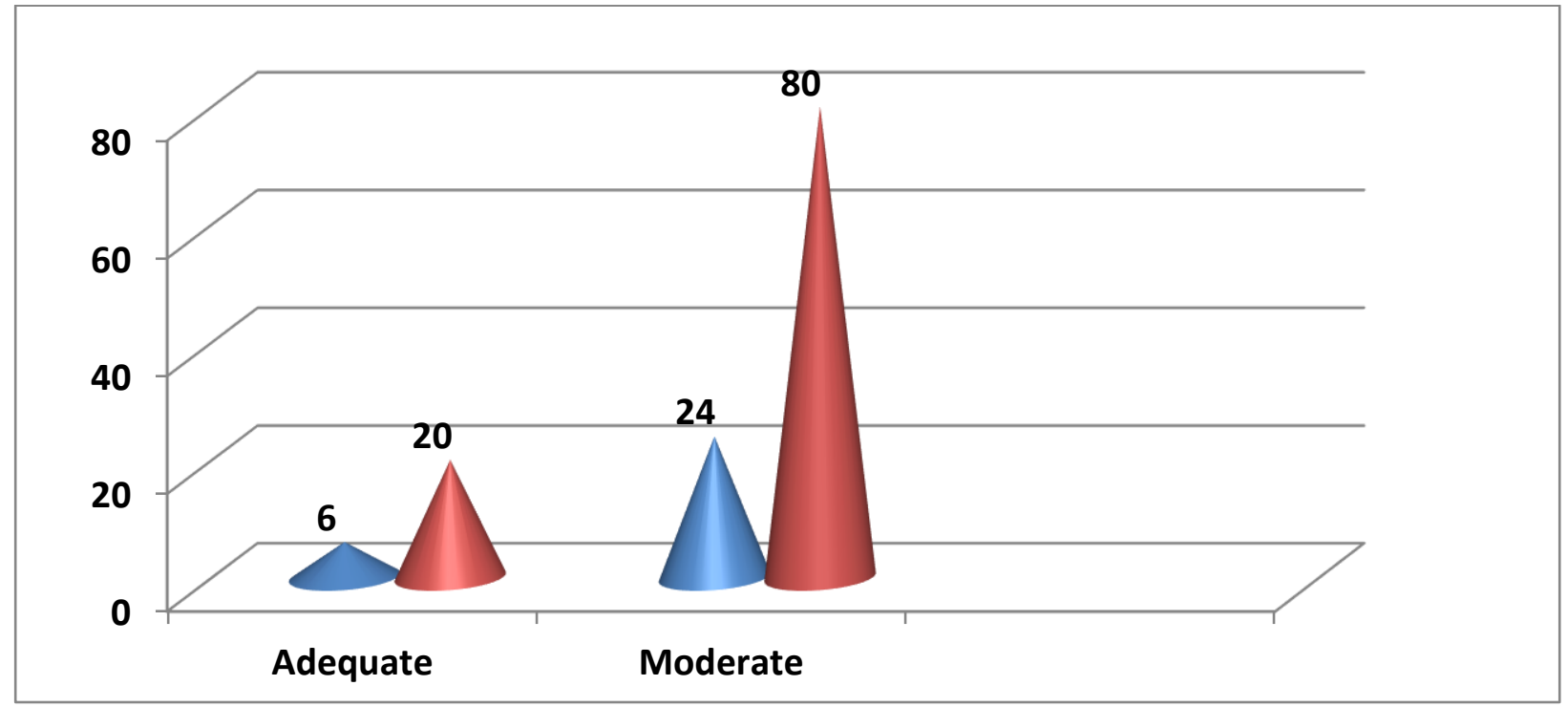

Fig 1 : Frequency and percentage distribution based on level of knowledge among III yr GNM students.

Table 2 : Frequency and percentage distribution of Mean and Standard deviation of knowledge.

\begin{tabular}{|l|l|l|}
\hline CATEGORY & MEAN & S.D \\
\hline Level of knowledge & 20.6 & 3.15 \\
\hline
\end{tabular}

Table 3: Association between level of knowledge and socio demographic variables among III yr GNM students.

$(\mathrm{N}=30)$ 


\begin{tabular}{|c|c|c|c|c|c|c|}
\hline \multirow[t]{2}{*}{ S. No } & \multirow[t]{2}{*}{$\begin{array}{l}\text { Demographic } \\
\text { Variables }\end{array}$} & \multicolumn{2}{|c|}{$\begin{array}{l}\text { Adequate } \\
\text { knowledge }\end{array}$} & \multicolumn{2}{|c|}{$\begin{array}{l}\text { Moderate } \\
\text { knowledge }\end{array}$} & \multirow[t]{2}{*}{ Chi Square } \\
\hline & & $\mathrm{F}$ & $\%$ & $\mathrm{~F}$ & $\%$ & \\
\hline 1. & $\begin{array}{l}\text { Age in years } \\
\text { a) } 18-20 \text { years } \\
\text { b)>20 years }\end{array}$ & 10 & $\begin{array}{l}33.3 \\
3.3\end{array}$ & $\begin{array}{l}17 \\
2\end{array}$ & $\begin{array}{l}56.6 \\
6.6\end{array}$ & $\begin{array}{l}\mathrm{C}=18.159 \\
\mathrm{~T}=12.59 \\
\mathrm{Df}=6 \\
\mathrm{P}<0.05 \\
\mathrm{~S}^{*}\end{array}$ \\
\hline 2. & $\begin{array}{l}\text { Working area } \\
\text { a)Medical wards } \\
\text { b)Surgical wards }\end{array}$ & $\begin{array}{l}1 \\
1\end{array}$ & $\begin{array}{l}2 \\
2\end{array}$ & $\begin{array}{l}2 \\
9\end{array}$ & $\begin{array}{l}4 \\
18\end{array}$ & $\begin{array}{l}\mathrm{C}=8.7049 \\
\mathrm{~T}=7.82 \\
\mathrm{Df}=3 \\
\mathrm{P}<0.05 \\
\mathrm{~S}^{*}\end{array}$ \\
\hline
\end{tabular}

\section{MAJOR FINDINGS OF THE STUDY}

Regarding the level of knowledge among GNM III yr students, 6, (20\%) had adequate knowledge, 22(73.3\%) had moderate knowledge and 2(6.6\%) had inadequate knowledge regarding physical examination.

$\checkmark$ The mean knowledge score of GNM III yr students was 20.6 and standard deviation was 3.15 .

$\checkmark$ There was a significant association found between level of knowledge and demographic variables such as age and working area at $\mathrm{P}<0.05$ level.

\section{CONCLUSION}

Hence it can be concluded that, majority of GNM III yr students, 22(73.3\%) had moderate knowledge on physical examination. Hence there is an immense need to implement an educational programme for all nursing students about physical examination.

\section{REFERENCES}

[1]. Carol Jaylor, "Text book of fundamentals of nursing", 4th edition, published by Lippincol, Page no.84-86.

[2]. Latha.P, A study to assess the knowledge regarding discharge procedure among staff nurses and nursing students in NMCH, Nellore, Narayana Nursing Journal, 2017, 6(3), 10-13.

[3]. Joyc T M.Blake, "Text book of medical and surgical nursing", 6th edition, published by Harcourt, Page no.110-115.

[4]. Riya Mathew, P Latha, N.Subhashini, Dr. Indira Arumugam A study to assess the knowledge regarding INC norms for b.sc nursing programme among nursing students in Narayana college of nursing, Nellore, International Journal of Academic Research and Development, 2017, 2(4), 655-656.

[5]. P.Latha, Anju mol, Level of Knowledge regarding IPR among staff nurses and students at NMCH, Nellore, 2016, 5(3), 19-21.

[6]. Arundathi S, Latha P, Dr. Indira Arumugam A study to assess the knowledge on factors affecting nursing practices among nursing staffs in NMCH at Nellore, International Journal of Advance Research in Nursing, 2019; 2(1), 1720. 
[7]. P.Latha, Anjaly Joseph, Dr.S.Indira Knowledge regarding recording \& reporting among staff nurses and nursing students at $\mathrm{NMCH}$, Nellore, International Journal of Applied Research, 2016, 2(11), 436-438.

[8]. Potter Perry, "The book fundamentals or nursing", 4th edition, published Mosby, Page no.671-771.

[9]. J Samhitha, Latha P, Dr. Indira Arumugam, A study to assess the knowledge on objective structured practical examination (OSPE) among B.sc Nursing students at selected college, Nellore, International Journal of Midwifery and Nursing Practice, 2018; 1(1), 16-18.

[10]. Lippincott (2000) "Manual of nursing practice;" 8th edition; Jaypee publication; New Delhi; p945-p954.

[11]. Tincy Thomas, P. Latha, Dr. Indira S, B. Kavitha, Knowledge regarding INC norms for post basic B.Sc nursing programe among faculty in Sree Narayana Nursing, Nellore, Andhra Pradesh, International Journal of Academic Research and Development, 2017, 2(4), 338340 .

\section{Cite this article as :}

Latha. A, Latha. P, Dr. Indira Arumugam, "An Observational Study to Assess the Knowledge Regarding Physical Examination among III Year GNM students at Narayana Medical College Hospital, Nellore, Andhra Pradesh", International Journal of Scientific Research in Science and Technology (IJSRST), Online ISSN : 2395-602X, Print ISSN : 2395-6011, Volume 6 Issue 2, pp. 719-724, MarchApril 2019. Available at doi : https://doi.org/10.32628/IJSRST1962120 Journal URL : http://ijsrst.com/IJSRST1962120 